\title{
Innate susceptibility differences in chinook salmon Oncorhynchus tshawytscha to Loma salmonae (Microsporidia)
}

\author{
R. W. Shaw ${ }^{1, *}$, M. L. Kent ${ }^{2}$, M. L. Adamson ${ }^{3}$ \\ ${ }^{1}$ \#9 26520 Twp Rd 512, Spruce Grove, Alberta T7Y 1G1, Canada \\ ${ }^{2}$ Center for Salmon Disease Research, 220 Nash Hall, Oregon State University, Corvallis, Oregon 937331-3804, USA \\ ${ }^{3}$ Department of Zoology, 6270 University Boulevard, University of British Columbia, Vancouver, British Columbia V6T 1Z4, Canada
}

\begin{abstract}
Loma salmonae (Putz, Hoffman and Dunbar, 1965) Morrison \& Sprague, 1981 (Microsporidia) is an important gill pathogen of Pacific salmon Oncorhynchus spp. in the Pacific Northwest. Three strains of chinook salmon $O$. tshawytscha were infected in 2 trials with L. salmonae by feeding of macerated infected gill tissue or per os as a gill tissue slurry. Intensity of infection was significantly higher in the Northern stream (NS) strain as compared to the Southern coastal (SC) and a hybrid (H) strain derived from these 2 strains. Both wet mount and histological enumeration of intensity of infection demonstrated strain differences. Survival in the NS strain was significantly lower than the other strains. The NS strain may represent a naive strain and be less able to mount an effective immune response against the parasite.
\end{abstract}

KEY WORDS: Loma salmonae $\cdot$ Microsporidia $\cdot$ Innate susceptibility

Resale or republication not permitted without written consent of the publisher

\section{INTRODUCTION}

Loma salmonae (Putz, Hoffman and Dunbar, 1965) Morrison \& Sprague, 1981 infects endothelial cells of Pacific salmon Oncorhynchus spp. and is considered a serious gill pathogen in the Pacific Northwest (Kent \& Poppe 1998, Shaw \& Kent 1999). This microsporidian parasite provokes hypertrophy of host cells in which spores are being formed. These parasite-host cell complexes are termed xenomas and found predominately in the gills, but also throughout vascularized tissue of the host. Xenomas can occlude blood vessels, rupture and result in a severe inflammatory response by the host when xenomas rupture releasing spores (Hauck 1984, Kent et al. 1989, Speare et al. 1989). These released spores can infect the same host forming another xenoma or be released to the environment and ingested by a new host (Shaw et al. 1998). Once in the

*E-mail: shawr@admin.gmcc.ab.ca alimentary canal a L. salmonae spore is stimulated to extrude a polar filament which pierces a host cell, injecting the infective sporoplasm. Shaw et al. (1998) suggested this sporoplasm may enter the blood stream through the lamina propria, eventually reaching and infecting an endothelial cell to form the xenoma.

Genetic variation between strains of fish from different geographic origins has been demonstrated for protist infections. Clayton \& Price (1992) noted both interand intraspecific variation in resistance to the ciliate Ichthyophthirius multifiliis Fouquet, 1876. Numerous studies have examined differential susceptibility of salmonid strains to the myxosporean Ceratomyxa shasta Noble, 1950 and haemoflagellate Cryptobia salmositica Katz, 1951 (Bower \& Evelyn 1988, Ibarra et al. 1991, 1992, 1994, Bower 1995, Bower et al. 1995, Forward et al. 1995, Forward \& Woo 1996). Both Chevassus \& Dorson (1990) and Wiegertjes et al. (1996) provide extensive reviews of genetic variation of resistance to disease in fish. However, no information exists on variation of strains of fish to infection by microsporidia. 
Production of 3 strains of pen-reared (farmed) chinook salmon Oncorhynchus tshawytscha by the aquaculture industry in British Columbia, Canada, resulted in anecdotal reports of different susceptibility to Loma salmonae in netpens. We investigated this further by infecting these strains of chinook salmon with L. salmonae under controlled laboratory conditions.

\section{MATERIALS AND METHODS}

Fish husbandry. Three strains of chinook salmon were obtained from Sea Springs Hatchery, Duncan, British Columbia, Canada, which receives only well water and has no history of Loma salmonae. The first strain is termed Southern coastal (SC) after wild stocks of Big Qualicum River, Vancouver, Island, Canada. The second strain is termed Northern stream (NS) after wild stocks entering the Yukon river in the Yukon Territory, and the last was a hybrid $(\mathrm{H})$ of these 2 strains. All fish were the same year class and were transferred to the Pacific Biological Station in Nanaimo, British Columbia, where they were held for $3 \mathrm{wk}$ to adapt to laboratory conditions. Fish received dechlorinated fresh water $\left(14\right.$ to $\left.16^{\circ} \mathrm{C}\right)$ in flow-through tanks and were fed daily to satiation a diet of commercial fish-feed. During handling, fish were anesthetized with tricaine methanesulfonate (MS-222).

Preparation of parasite. The protocol of Kent et al. (1995) was followed for preparation of macerated gill tissue and the protocol of Shaw et al. (1998) was followed for preparation of an infective gill tissue slurry.

Exposure protocol. Susceptibility of the chinook strains was examined in 2 separate trials. In the first trial 70 fish per strain (average total length and weight SC: $11.0 \mathrm{~cm}, 11.6 \mathrm{~g}$; NS: $9.3 \mathrm{~cm}, 6.9 \mathrm{~g}$; $\mathrm{H}: 12.9 \mathrm{~cm}$, $21.0 \mathrm{~g}$ ) were fin-clipped, placed in separate $726 \mathrm{l}$ deepoval tanks (fresh water, $18^{\circ} \mathrm{C}$ ), food withheld for $2 \mathrm{~d}$, and then fed $23.8 \mathrm{~g}$ of macerated Loma salmonae infected gill tissue per tank over $3 \mathrm{~d}$, using the same inoculum for each tank. On Day 4 all fish were placed in 1 tank and 17 negative controls per strain were added. Fish were examined for presence of $L$. salmonae only by histology 27 d later because of high mortality. Every $12 \mathrm{~h}$ during this trial, presence of $L$. salmonae was also recorded by wet mount examination of gills in fish that had died, as the gills of these fish were too autolysed for examination by histology. Viscera from 20 fish per strain were preserved for histological examination to evaluate systemic infections by L. salmonae.

For Trial 2, a group of 120 fish per strain (average total length and weight SC: $12.3 \mathrm{~cm}, 22.0 \mathrm{~g}$; NS: $9.5 \mathrm{~cm}$, $10.0 \mathrm{~g}$; H: $11.6 \mathrm{~cm}, 18.0 \mathrm{~g}$ ) were individually identified with pit tags (BioSonics Inc., Seattle, WA), and held in tanks for 4 wk to heal from tagging. A total of 100 fish per strain were exposed to Loma salmonae per os (infective gill tissue slurry introduced directly into the stomach) at $1.1 \times 10^{6}$ spores per fish, and placed in 1 deep-oval (726 l) tank. One day later, 10 negative controls per strain were added. Every $12 \mathrm{~h}$ prevalence and intensity of L. salmonae were recorded by wet mount in fish that died during the trial. Intensity was not recorded in gills of fish that were too autolysed for accurate evaluation. At 43 d (approximately 50\% mortality overall), all remaining fish were examined by histology and wet mount.

Evaluation methods. At sampling fish were killed with an overdose of MS-222 and total length and weight of each fish was taken. The first left gill arch of each fish was examined by wet mount for Loma salmonae and intensity enumerated from the average of 3 random counts of the number of xenomas per $\times 100$ field of view (1.5 mm diameter) and converted to xenomas $\mathrm{mm}^{-2}$ gill tissue. The remainder of the gills were placed in Davidson's solution (Humason 1979) along with complete viscera and a section of dorsal muscle for histology. All these tissues were processed using standard histological techniques. Histological sections of these tissues were stained with hematoxylin and eosin and examined at $\times 100$. Intensity was enumerated in histological sections using the same methods described above for wet mounts.

Before fish were exposed, the left gill arch of 30 fish from each strain was examined by wet mount and histology for any infection by Loma salmonae.

Statistics. All prevalence data was tested using a chisquare test for goodness of fit. Intensity data was log transformed $x^{\prime}=\log (x+1)$, then tested with an analysis of variance (ANOVA), followed by a Tukey Honestly Significantly Different (THSD) test. Histological and wet mount enumeration were compared as an estimate of parasite abundance in Trial 2. Time to death and survival was also tested for Trial 2 first by ANOVA, then by THSD test. Weights and lengths from all strains were tested with a Spearman rank correlation against their respective intensity of infection.

\section{RESULTS}

All fish examined before exposure were negative for Loma salmonae infection. We observed clinical signs of lethargy, flared opercula, darkening of the tail or body in moribund fish and gill pallor, ascites, hemorrhagic pyloric caeca, petechial hemorrhaging in the gills, skin and fins and numerous xenomas on the gills in dead fish from both trials. There were no significant differences between strains in prevalence of infection; however, intensity was significantly higher $(\mathrm{p}<0.001$; 
Table 1. Loma salmones infecting Oncorhynchus tshawytscha. Prevalence and intensity of infection in 3 strains of chinook salmon after exposure by feeding infected gill tissue (Trial 1) or administration per os (Trial 2) of an infected gill slurry. Controls represent cohabitating but non-experimentally infected fish

\begin{tabular}{|c|c|c|c|c|c|c|c|c|}
\hline \multirow{2}{*}{$\begin{array}{l}\text { Screening } \\
\text { method }\end{array}$} & \multicolumn{4}{|c|}{ Prevalence $^{a}$} & \multicolumn{4}{|c|}{ Xenoma intensity $^{\mathrm{b}}$} \\
\hline & $\begin{array}{l}\text { Southern } \\
\text { coastal }\end{array}$ & $\begin{array}{l}\text { Northern } \\
\text { stream }\end{array}$ & Hybrid & Control & $\begin{array}{c}\text { Southern } \\
\text { coastal }\end{array}$ & $\begin{array}{l}\text { Northern } \\
\text { stream }\end{array}$ & Hybrid & Control \\
\hline $\begin{array}{l}\text { Histology } \\
(\text { Trial 1) }\end{array}$ & $54 / 55$ & $43 / 43$ & $56 / 62$ & $0 / 51$ & $1.7(0.0-4.5)$ & $1.9(1.0-6.4)$ & $0.9(0.0-10.2)$ & $0.0(0.0-0.0)$ \\
\hline $\begin{array}{l}\text { Histology } \\
\text { (Trial 2) }^{d}\end{array}$ & $59 / 59$ & $35 / 36$ & $51 / 51$ & $0 / 30$ & $1.0(0.1-6.0)$ & $4.4(0.4-20.9)$ & $1.0(0.0-5.0)$ & $0.0(0.0-0.0)$ \\
\hline $\begin{array}{l}\text { Wet mount } \\
\text { (Trial 2) }\end{array}$ & $58 / 59$ & $36 / 36$ & $51 / 51$ & $0 / 30$ & $6.1(0.0-17.0)$ & $18.1(6.4-38.5)$ & $5.1(1.2-13.9)$ & $0.0(0.0-0.0)$ \\
\hline
\end{tabular}

1 outlier omitted in Trial 1) in the NS strain for both trials (Tables $1 \& 2$ ). Days to death did not differ significantly ( $p=0.152)$ between strains of chinook. Histological or wet mount enumeration did not affect the ability to detect strain differences, although more xenomas were detectable by wet mount. Survival in the NS strain was also significantly lower ( $<$ 0.05) (Fig. 1). L. salmonae was distributed in all organs sampled with some previously undocumented xenomas in the pyloric caeca, dermis, and mesentery (Table 3 ). There was no significant correlation $(p<0.05)$ with weight or length of fish and intensity of infection.

\section{DISCUSSION}

In general most fish are susceptible to initial infections but differ in their ability to limit or destroy pathogens (Wiegertjes et al. 1996). The terminology 'resistant' and 'susceptible' therefore, is always relative, and thus a reproducible method of exposure is vital in demonstrating differences between strains. Our first trial employed feeding of macerated gill tissue and larger fish may have consumed more gill tissue,

Table 2. Loma salmones infecting Oncorhynchus tshawytscha. Average xenoma intensity in gills from mortalities of 3 strains of chinook salmon infected per os with $L$. salmonae during a $43 \mathrm{~d}$ holding period at 14 to $16^{\circ} \mathrm{C}$ (Trial 2). Mortalities with extremely autolysed gills (unreadable) were not evaluated

\begin{tabular}{|lc|}
\hline Strain (no. of mortalities evaluated) & Xenoma intensity ${ }^{\mathrm{a}}$ \\
\hline Southern coastal (19) & $6.6(2.3-13.1)$ \\
Northern stream (19) & $16.2(2.4-42.1)$ \\
Hybrid (18) & $7.3(3.5-11.9)$ \\
a Avg. xenoma intensity $\mathrm{mm}^{-2}$ (range) in mortalities over 43 d \\
\hline
\end{tabular}

leading to a higher intensity of infections. High mortalities in both trials were likely due to infection by Loma salmonae as fish exhibited typical clinical signs, e.g. gill pallor and hemorrhaging, ascites, and numerous xenomas in the gills (Hauck 1984, Kent \& Poppe 1998). Trial 1 was terminated earlier than Trial 2 (i.e. 27 vs $43 \mathrm{~d}$ post-infection respectively) due to high mortalities. Mortalities in Trial 1 may have occurred earlier than Trial 2 as a result of the higher water temperature $\left(18^{\circ} \mathrm{C}\right.$ vs 14 to $16^{\circ} \mathrm{C}$ respectively). Development of $L$. salmonae proceeds more rapidly at higher water temperatures (Beaman et al. 1999), and more severe disease has been noted in coho salmon Oncorhynchus kisutch in the spring when water temperatures are rising (Kent et al. 1989).

Although both trials demonstrated differences between the chinook strains, per os exposure of fish (Trial 2) to equal doses of Loma salmonae is the consistent, reproducible method. For Trial 2 (per os expo-

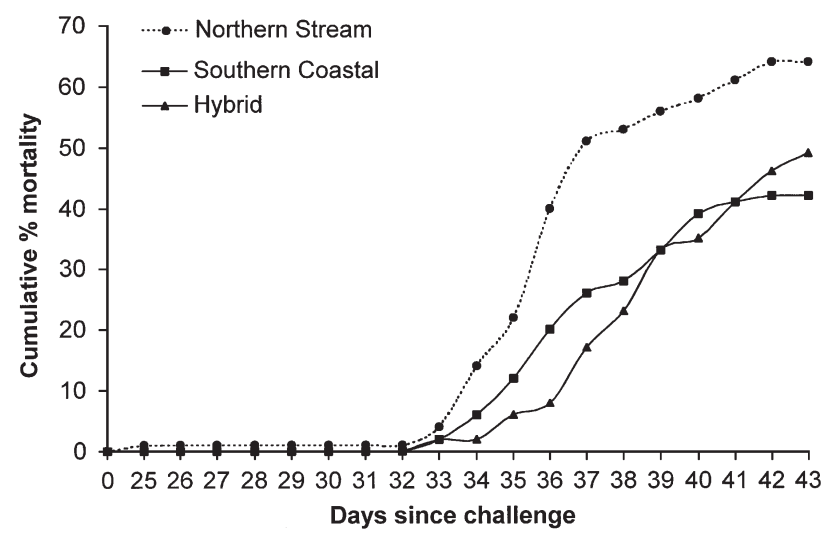

Fig. 1. Loma salmones infecting Oncorhynchus tshawytscha. Cumulative percent mortality in 3 strains of chinook salmon over time after per os infection with $L$. salmonae and being held for $43 \mathrm{~d}$ at 14 to $16^{\circ} \mathrm{C}$ 
Table 3. Loma salmones infecting Oncorhynchus tshawytscha. Organ distribution of L. salmonae in 3 strains of chinook salmon after exposure by feeding infected gill tissue (Trial 1) or administration per os (Trial 2) of an infected gill slurry. Values are percentage of fish showing infection in organ indicated. -: not determined

\begin{tabular}{|c|c|c|c|c|c|c|c|c|c|c|c|}
\hline Trial & Strain & $\begin{array}{l}\text { No. fish } \\
\text { examined }\end{array}$ & Gill & Heart & Kidney & Spleen & $\overline{\text { Liver }}$ & $\begin{array}{l}\text { issue } \\
\text { Intestine }\end{array}$ & Pyloric caeca & Dermis & Mesentery \\
\hline \multirow[t]{3}{*}{$1^{\mathrm{a}}$} & Southern coastal & 20 & 100.0 & 20.0 & 0.0 & 30.0 & 1.0 & - & - & - & - \\
\hline & Northern stream & 20 & 100.0 & 10.0 & 0.0 & 40.0 & 0.0 & - & - & - & - \\
\hline & Hybrid & 20 & 100.0 & 20.0 & 35.0 & 30.0 & 0.0 & - & - & - & - \\
\hline \multirow[t]{3}{*}{$2^{b}$} & Southern coastal & 58 & 100.0 & 39.7 & 31.0 & 32.8 & 1.7 & 1.7 & 5.2 & 1.7 & 0.0 \\
\hline & Northern stream & 51 & 100.0 & 68.6 & 96.1 & 49.0 & 1.7 & 5.9 & 9.8 & 7.8 & 9.8 \\
\hline & Hybrid & 36 & 97.2 & 16.7 & 58.3 & 8.3 & 0.0 & 8.3 & 5.5 & 2.8 & 5.5 \\
\hline
\end{tabular}

sure) intensity of infection was significantly higher and survival significantly lower in the NS strain compared to the other 2 strains. Bower et al. (1995) found that coho salmon from the Kitimat River were highly susceptible to Cryptobia salmositica compared with coho from Big Qualicum River. They postulated that this may be because the parasite and it's vector are not enzootic to the Kitimat River. Shaw et al. (2000) found that wild NS chinook sampled for L. salmonae were negative while many other Pacific salmon spp. were positive. Although they sampled only 60 chinook from the Yukon river, their results and ours suggest this strain may represent a naive strain. The northern distribution of NS chinook may exceed the natural distribution of L. salmonae.

Natural disease resistance in fish is a complex interaction of genetic and non-genetic factors that may have multiple components (Chevassus \& Dorson 1990). Price (1985) discusses genetic factors that include: barriers (i.e. skin and mucous); effects on pathogens of the host environment (i.e. gastric secretions, pH of blood, deficiencies in compounds required by the pathogen, natural antitoxins); and humoral and/or cellular immune responses. Non-genetic factors may include pathogen abundance, virulence, and temperature effects on pathogen development (Ibarra et al. 1994). Differences in disease resistance between strains of fish have been linked to variation in levels of mucus precipitin activity (Cipriano et al. 1994), plasma lipid components (Maita et al. 1998), antibody production (Strønsheim et al. 1994a,b), complement (Røed et al. 1990, 1992, 1993), and respiratory burst activity in head kidney macrophages (Balfry et al. 1994).

We found that significantly fewer NS chinook survived than $\mathrm{SC}$ or $\mathrm{H}$ and that there were no differences in time to death. Survivability is considered the best criterion for evaluating resistance in strains of fish as this represents the sum of all host-parasite interactions (Wassom \& Kelly 1990). Ibarra et al. (1991) noted that only $13 \%$ of the Ceratomyxa shasta resistant strain of rainbow trout died compared with $90 \%$ of the susceptible strain, although they did not find any difference in time to death (Ibarra et al. 1994). Studies of C. shasta suggest 2 interacting mechanisms influencing parasite establishment: success of initial invasion by the parasite and the ability of the fish to mount an effective immune response (Ibarra et al. 1994). Loma salmonae may be unable to infect endothelial cells of resistant hosts and/or establish itself because of the immune response of the host. Macrophages are believed to be the primary defense mechanism of fish against microsporidia and phagocytosis and destruction of spores by macrophages has been described for several fish-infecting microsporidian species (Dyková \& Lom 1980, Canning \& Lom 1986). Shaw (1999) found that macrophages of Atlantic salmon Salmo salar, which are resistant to L. salmonae, phagocytosed more spores than susceptible chinook salmon. Although he did not find significant differences between SC and NS chinook strains using this assay, he postulated other immune mechanisms (e.g. respiratory burst) might account for this.

The NS fish in both experiments were smaller than the other strains, and thus the possibility that size affected the intensity of infection had to be considered. However, we found no relationship between size and intensity within the 3 strains.

In conclusion, Loma salmonae continues to be a serious gill pathogen in wild and farmed Pacific salmon. We found a chinook strain endemic to the Yukon river to be more susceptible to infection by the parasite when compared to a local strain from the Big Qualicum river, confirming the observations of fish farmers from netpen farms. The NS strain may represent a naive strain which is unable to mount as effective an immune response to the parasite. Future breeding experiments can further clarify these differences and investigate the underlying mechanisms. 
Acknowledgements. This project was funded by NSERC strategic grant number 582073. We thank Sheila Dawe for technical assistance, the fish farming companies that participated in the research, and the Department of Fisheries and Oceans, Nanaimo, British Columbia, for providing experimental facilities.

\section{LITERATURE CITED}

Balfry SK, Iwama GK, Evelyn TPT (1994) Components of the non-specific immune system in coho salmon associated with strain differences in innate disease resistance. Dev Comp Immunol 18:S82

Beaman HJ, Speare DJ, Brimacombe M (1999) Regulatory effects of water temperature on Loma salmonae (Microspora) development in rainbow trout. J Aquat Anim Health 11:237-245

Bower SM (1995) Differences in acquired and innate resistance among Pacific salmon (Oncorhynchus spp.) against the haemoflagellate Cryptobia salmositica and numbers delivered by the leech vector Piscicola salmositica. Can J Fish Aquat Sci 52(Suppl.1):1-6

Bower SM, Evelyn TPT (1988) Acquired and innate resistance to the haemoflagellate Cryptobia salmonsitica in sockeye salmon (Oncorhynchus nerka). Dev Comp Immunol 12: 749-760

Bower SM, Withler RE, Ridell BE (1995) Genetic variation in resistance to the haemoflagellate Cryptobia salmositica in coho and sockeye salmon. J Aquat Anim Health 7: 185-194

Canning EU, Lom J (1986) The microsporidia of fish. In: Canning EU, Lom J (eds) The microsporida of vertebrates. Academic Press, New York, p 17-171

Chevassus B, Dorson M (1990) Genetics of resistance to disease in fishes. Aquaculture 85:83-107

Cipriano RC, Ford LA, Jones TE (1994) Relationship between resistance of salmonids to furunculosis and recovery of Aeromonas salmonicida from external mucus. J Wildl Dis 30:577-580

Clayton GM, Price DJ (1992) Interspecific and intraspecific variation in resistance to ichthyophthiriasis among poeciliid and goodeid fishes. J Fish Biol 40:445-453

Dyková I, Lom J (1980) Tissue reactions to microsporidian infections in fish. J Fish Dis 3:265-283

Forward GM, Woo PKT (1996) An in vitro study on the mechanism of innate immunity in Cryptobia-resistant brook char (Salvelinus fontinalis) against Cryptobia salmositica. Parasitol Res 82:238-241

Forward GM, Ferguson MM, Woo PKT (1995) Susceptibility of brook charr, Salvelinus fontinalis to the pathogenic haemoflagellate, Cryptobia salmositica, and the inheritance of innate resistance by progenies of resistant fish. Parasitology 111:337-345

Hauck AK (1984) A mortality and associated tissue reactions of chinook salmon, Oncorhynchus tshawytscha (Walbaum), caused by the microsporidan Loma sp. J Fish Dis $7: 217-229$

Humason GL (1979) Animal tissue techniques, 4th edn. WH Freeman and Company, San Francisco, CA

Ibarra AM, Gall GAE, Hedrick RP (1991) Susceptibility of two strains of rainbow trout Oncorhynchus mykiss to experimentally induced infections with the myxosporean Ceratomyxa shasta. Dis Aquat Org 10:191-194
Ibarra AM, Hedrick RP, Gall GAE (1992) Inheritance of susceptibility to Ceratomyxa shasta (Myxozoa) in rainbow trout and the effect of length of exposure on the liability to develop ceratomyxosis. Aquaculture 104:217-229

Ibarra AM, Hedrick RP, Gall GAE (1994) Genetic analysis of rainbow trout susceptibility to the myxosporean, Ceratomyxa shasta. Aquaculture 120:239-262

Kent ML, Poppe TT (1998) Diseases of seawater netpen-reared salmonid fishes. Pacific Biological Station, Nanaimo, British Columbia

Kent ML, Elliott DG, Groff JM, Hedrick RP (1989) Loma salmonae (Protozoa:Microspora) infections in seawater reared coho salmon Oncorhynchus kisutch. Aquaculture 80:211-222

Kent ML, Dawe SC, Speare DJ (1995) Transmission of Loma salmonae (Microsporea) to chinook salmon in sea water. Can Vet J 36:98-101

Maita M, Satoh K, Fukuda Y, Lee H, Winton JR, Okamoto N (1998) Correlation between plasma component levels of cultured fish and resistance to bacterial infection. Fish Pathol 33:129-133

Price DJ (1985) Genetics of susceptibility and resistance to disease in fishes. J Fish Biol 26:509-519

Røed KH, Brun E, Larsen HJ, Refstie T (1990) The genetic influence on serum haemolytic activity in rainbow trout. Aquaculture 85:109-117

Røed KH, Fjalestad KT, Laersen HJ, Midthjel L (1992) Genetic variation in haemolytic activity in Atlantic salmon (Salmo salar). J Fish Biol 40:739-750

Røed KH, Fjalestad KT, Stønsheim A (1993) Genetic variation in lysozyme activity and spontaneous haemolytic activity in Atlantic salmon (Salmo salar). Aquaculture 114:19-31

Shaw RW (1999) Biology of Loma salmonae (Microsporidia). $\mathrm{PhD}$ thesis, University of British Columbia, Vancouver, British Columbia

Shaw RW, Kent ML (1999) The Microsporidia and Microsporidiosis. In: Wittner M, Weiss LM (eds) Fish microsporidia. ASM Press, Washington, DC, p 418-446

Shaw RW, Kent ML, Adamson ML (1998) Modes of transmission of Loma salmonae (Microsporidia). Dis Aquat Org 33: 151-156

Shaw RW, Kent ML, Adamson ML (2000) Host specificity and prevalence of Loma salmonae (Microsporidia) under laboratory and natural conditions. Dis Aquat Org 40:131-136

Speare DJ, Brackett J, Ferguson HW (1989) Sequential pathology of the gills of coho salmon with a combined diatom and microsporidian gill infection. Can Vet J 30:571-575

Stønsheim A, Eide DM, Fjalestad KT, Larsen HJS, Røed KH (1994a) Genetic variation in the humoral immune response in Atlantic salmon (Salmo salar) against Aeromonas salmonicida A-layer. Vet Immunol Immunopathol 41:341-352

Stønsheim A, Eide DM, Hofgaard PO, Larsen HJS, Refstie T, Røed KH (1994b) Genetic variation in the humoral immune response against Vibrio salmonicida and in antibody titre against Vibrio anguillarum and total IgM in Atlantic salmon (Salmo salar). Vet Immunol Immunopathol 44:85-95

Wassom DL, Kelly EAB (1990) The role of the major histocompatibility complex in resistance to parasitic infections. Crit Rev Immunol 10:31-52

Wiegertjes GF, Stet RJM, Parmentier HK, Muiswinkel WBV (1996) Immunogenetics of disease resistance in fish: a comparative approach. Dev Comp Immunol 20:365-381 